\title{
The Impacts of Task-based Teaching on Grammar Learning by Iranian First Grade High School Students
}

\author{
Seyyed Morteza Tale \\ Chabahar University, Iran \\ E-mail: hojjat_tale@yahoo.com \\ Ahmad Goodarzi (Corresponding author) \\ Arak University, Iran \\ E-mail: ahmad.goodarzi1234@gmail.com
}

Received: 07-12- 2014

Published: 01-07-2015
Accepted: 08-02- 2015

doi:10.7575/aiac.ijalel.v.4n.4p.144
Advance Access Published: February 2015

URL: http://dx.doi.org/10.7575/aiac.ijalel.v.4n.4p.144

\begin{abstract}
During last decades, new methods and approaches were put forward to resolve teaching grammar problem. Among them, Task-Based Language Teaching (TBLT), focusing on learner's involvement in tasks, tried to prepare efficient learners for successful handling of real-world performance and communication. The present study aims at investigating the impact of Task-Based Instruction (TBI) on grammar learning of elementary EFL Learners and their motivation after implementing TBI. In so doing, 74 Elementary EFL learners were selected randomly and whose proficiency level and grammar homogeneity were established via administering a Nelson grammar proficiency test and Michigan grammar test, respectively. Then, the treatment group enjoyed TBI by implementing different tasks for about fifteen 35-minute sessions. The control group benefited the same amount of grammar instruction, but not through the TBI. At the end, students of both groups were given the Michigan grammar-oriented post-test to gauge the effect of TBLT on improving the grammar proficiency of the learners. The data were analyzed through statistical techniques of t-test. The results revealed that TBI had a significant impact on promoting the grammar proficiency of Iranian elementary EFL learners. Moreover, by analyzing the mean of experimental group, it is understood that the level of motivation was high. The study concluded that TBI instruction on grammar could be used effectively for Iranian language learners especially for the improvement of their motivation.
\end{abstract}

Keywords: Task-Based Instruction, Motivation, Grammar, Task, Communicative Approach

\section{Introduction}

Linse (2005) states that language learning, mainly, covers four areas of speaking, listening, writing, and reading and there is a clear relationship between all these skills. Newby (2003) believes that, "grammar is a subsystem in a network of other linguistic sub-systems and sub-skills". Grammar is an essential component in language teaching and learning. It is also one of the most difficult aspects of language teaching. Throughout history of language teaching, several different approaches to foreign language learning and teaching have been introduced. Consequently, grammar is undergoing changes by different methods. For example, it was the central aspect of learning in the Grammar Translation Method, while the Direct Method and Natural Approach viewed grammar in a marginalized way (Brown, 2007). Lock (1997) mentioned some of the dichotomies that considered when working with grammatical structure instruction, which are form vs. meaning, form vs. function, meaning-based instruction vs. form-based instruction, fluency vs. accuracy, and the most emphasized one: grammar vs. communication.

Teaching language communicatively was first affected by with a notional functional view of language by linguists, and then, the meaning, function, and communication would be encompassed within the study of grammar and linguists should concentrate on the language use rather than on its grammatical rules itself. Consequently, meaning-based approaches appeared and Task-Based Language Teaching (TBLT) was generated from these communicative approaches. In TBLT, a task is the main focus of instruction as it engages the learners in fulfilling the meaning-focused activities (Eliss, 2003).

Therefore, the aim of the study was to investigate the impact of the task-based instruction on promoting grammar mastery. Another goal of the research was to examine the motivation of the EFL students in learning grammar structures and to find whether TBLT has any impact on the motivation of the leaners or not.

\section{Literature Review}

\subsection{Grammar}

Brown (2001) defined grammar as "The system of rules governing the conventional arrangement and relationship of words in a sentence... Technically grammar refers to sentence-level rules only, and not rules governing the relationship among sentences, which it refers to as discourse rules" (p. 362). 
In the eighth edition of Oxford Advanced Learner's Dictionary (2010), grammar is defined as "study or science of, rules for, the words into sentences (syntax), and the forms of words (morphology)". The first edition of Longman Dictionary of Contemporary English (2009) has defined grammar as "the study of use of the rules by which words change their forms and are combined into sentences".

Grammar has been taught in universities and colleges majoring English language for years. Chang (2011) stated that ensuring the accuracy of the sentences mainly is highly reliant on the learner's grammar proficiency. Due to the forementioned facts, implementing grammar instruction productively and efficiently is a consequential task for language researchers and teachers. The modern way of teaching grammar in schools is still presented by the traditional teaching methods, which resembles GTM and ALM. In this model, language forms are introduced by the instructor, then elaborated in the speaking or writing activities, and then implemented by the learners in less controlled spoken or written activities (Chang, 2011). Of course the traditional grammar teaching method gives the learners the opportunity to extend mastery of the grammatical structures, but the learners cannot use these structures properly in conversation. This could be said that the GTM and ALM has the disadvantage which keeps the students away from raising their communicative competence, due to the fact that the traditional grammar teaching is teacher-centered. In these classes, teachers explain English grammatical structures and all the students pay a direct attention to them. So, communicative competence is ignored to some extent. The use of the English language is little. The main exercise is to translate texts from English into Native Language or vice versa, to fill in the blank and to judging erroneous sentences. So the students face no communicative tasks. In GTM and ALM, memorizing and rote-learning are the main ways, which cannot increase students' favors and develop their learning strategies and, of course, forces them to be afraid of grammatical structure learning. Another grammar instruction method is the Communicative Approach. The Communicative Approach makes language teaching as in real-world context. Chang (2011) hold that grammar learning occurs via communication through learners' attendance or cooperation of teaching tasks between or among learners and teachers, and then grammatical structures can be learned naturally by learners.

\subsection{Task based language teaching}

During the last two decades, task based language teaching (TBLT) received a lot of attention of second language acquisition (SLA) researchers, teachers, curriculum developers, and teacher trainers (Branden, 2006). The SLA researchers and language instructors made a term, in response to rule-based SL classroom activities (Long \& Norris, 2000). Long (1985) and Prabhu (1987)supported a framework in which learners experience functional tasks that let them concentrate on meaningful tasks and language use (Branden, 2006).In the TB instruction, the aim is to make a requirement to learn and use language. The tasks will create their own language and produce a chance for learning language explicitly.

Willis and Willis (2007) have created a task-based framework. This task-based framework creating a connection between the language tasks and pedagogic unit includes three sections and some sub-parts (Willis, D., \& Willis, J., 2007).According to this framework, instructors do not explicitly make the structures to be taught and the vocabulary to be covered in a unit, but they use tasks to achieve some ends, according to the students' needs and favors. Besides, it might go beyond the traditional method of setting language instruction introduced by Skehan (1998) as the 3 Ps, Presentation, Practice and Production (Eliss, 2003). There are some advantages to this framework. This framework moves beyond the concept of assessment in a traditional view. TBLT framework can help teachers and students have opportunities for communication. This approach has to be amalgamated with the three following factors, language awareness, the intercultural competence, and the content-based approach.

\subsubsection{Grammar in Task-Based Approach}

One approach to language teaching that has received much attention over the last years is task-based approach. In taskbased instruction, the focal point of classroom activities is on tasks, and secondly on meaning. Jane Willis's model of TBI (1996) is one of the best in which Learners start by doing a communicative task, with no focus on form. After doing the task and completed them, they elaborate how they did it. The advantage of the task-based approach is that during the task the students are permitted to put to use whatever language they wish, letting them to concentrate, completely, on the meaning of their utterances. This makes a similar real communicative situation (Richards \& Rodgers, 2001). One of the disadvantages of TBLT is that the Learners become fluent, but their speeches are not often uttered correctly. However, they use strategies to fulfill the tasks quite rapidly and develop a shortcut in their language use and form.

\subsection{Motivation}

With regard to the rising interest in motivation in SLA, Ushioda (2009) stated that: "Primarily, SLA researchers have been interested in motivation because it seems to play such an important role in whether learners learn or not, how much effort they put into learning, how long they persist at learning, and how successfully they learn a language" (p. 218). Motivation is very important in educating a child, hence teachers and students should be motivated enough to teach and to learn well. Children are naturally curious and eager to learn new things. As children become older, their motivation fades. At this point parents and teachers must find ways to keep students involved in the learning process.

Motivation is psychological matter that awakens an individual to behave towards a desired end and extracts, manages, and keeps up certain end directed actions. It can be viewed a driving power; a psychological one that forces or fortifies a behavior toward a desired end. (Schacter, 2011, p. 325).Motivation has roots in physiological, behavioral, cognitive, and social areas (Schacter, 2011).To put it shortly, motivation could be viewed as the aim for, or a psychological reason of an action (Today, 2013). 


\section{3.1 Motivation in Education}

Motivation is an interesting issue for educationalist because of the vital part it has in learner's educational achievements. However, the motivation studied in pedagogy is different from the general aspects of motivation.

Motivation in pedagogy has some impacts on how learners acquire and how they handle subject matter. It can:

1. Control behavior toward specific ends

2. guide to extended exertion and energy

3. escalate beginning of, and permanence in, tasks

4. improve cognitive processes

5. settle what results would be

6. guide to the extendedachievement (Vallerand, Pelletier, Blais, Brière, Senécal ,1992).

\subsection{Previous Studies}

Bugler \& Hunt (2002) conducted a research at a Japanese university with nearly 340 first year students attending in a speaking class to investigate how tasks could be implemented as a foundation of teaching. The participants were needed to work in two-four person groups and to pick out a topic they favoured. Then, the groups made a questionnaire to analyse the viewpoints of a peculiar target group about the selected theme. The findings revealed that the experiencing TBI was pleasant, intrinsically interesting, and educationally helpful for the learners who attended in the task-based classes; therefore, the final product was highly qualified. The results of the study also proved that working collaboratively on tasks provide learners with a chance to act beyond the abilities of any student, which resulted in helpful educational gains besides motivating learners to resume doing the tasks.

Using task-based materials in the language classroom exposed EFL/ESL learners to the real-life use from the starting point of language research. The materials reflected a naturalness of rules (Rogers \& Medley, 1988). Based on the results of the study, the grammar learning in EFL/ESL leaners showed to develop through exposure to TB incoming data.

Another study was conducted by Lopez(2004) to use TBI to teach English in two classes in a school in Brazil instead of presentation-practice-production (PPP). He found that because in TBI students were manipulating the language to reach information, solve problems, and to state life experiences, they learned English more effectively. Moreover, they could handle real-life situations when they faced them outside the classroom because they enjoyed authentic materials that involved the learners in the real-like tasks. The findings of Lopez's study affirmed the principle of the sociocultural perspective that stated social interaction facilitates learning through the process of scaffolding. Providing learners with authentic material also affected their performance in fulfilling the tasks and consequently the real-world situation.

Fotos and Ellis (1991) revealed that the choosing of "task-based language teaching" to communicate about grammar is helpful to both learning and communication. They also revealed that teaching grammar communicatively with TBI helped Japanese EFL students improved their understanding of difficult grammatical forms.

In a semi-experimental research with the title of the effect of Task-based method on learning of There is/ there are in English, Mohammadi (2006) investigated the effect of TBI on elementary students in Isfahan. Findings showed that TBI had a significant effect on students. The traditional approach does not have a significant effect on students' learning and did not guarantee the success of students (Mohammadi, 2006).

\section{Method and Design of the Study}

The present study had a quasi-experimental intact design in which data were collected to examine the effect of two different tasks on grammar proficiency.

\subsection{The Question of the Study}

The two following research questions were addressed:

1. Is Task-based instruction significantly more effective than traditional grammar instruction on the grammatical proficiency of first grade high school students?

2. Does task based instruction have any significant impact on the motivation of the first grade high school students in improving their grammatical proficiency?

\subsection{Hypotheses}

1. Task-based instruction is significantly more effective than traditional grammar instruction on the grammatical proficiency of first grade high school students?

2. Task based instruction has some significant impact on the motivation of the first grade high school students in improving their grammatical proficiency

\subsection{Subjects}

This is study was done in 2 high schools in Chabahar, Iran. The number of students was 35 in control group and 39 in the experimental group. All of the students were male and their first language was Persian or Baluchi.

\subsection{Instrumentation}

The study employed two different instruments: instructional and testing materials. Here the researchers present an overview of the utilized instruments. 
In this study, two pre-tests were administered: the Nelson test $(050 \mathrm{~A})$ ensuring the participants' level of English command as elementary EFL learners and and Cambridge Michigan Grammar Test to ensure their grammar proficiency as elementary-level EFL learners. Then a questionnaire was given to learners to investigate their motivation.

A motivation questionnaire was administered at the beginning as well as the end of the experimental. It was developed to elicit relevant information on the participants' level of educational motivation. The questionnaire was given before instruction to find the level of their motivation.

The course book used for instruction in both groups was 1st grade high school English book which has 6 lessons. It was taught as the Instructional material. Besides this course book, for the purposes of this study,different worksheet and games and task activities were used. The source for the task activities was the fresh ideas of the authors of interchange series Richards (2013), Littlejohn \& Hicks (1997) and Oxenden, \& Latham-koeni (2008).

The same pre-test of grammar proficiency, namely Michigan grammar test that was administered prior to the treatment to ensure the comparability of the two groups' grammar proficiency with regard to the grammatical points included in their text book at the beginning of the study, was applied as the post-test at the end of the instruction to determine the possible progress in the grammar proficiency of the participants.

\subsection{Procedures}

The study was conducted in two high schools for male students in Chabahar, Iran. There were 2 groups of subjects in this study. In experimental group the number of subjects was 39 and in control group the number of subjects was 35 . They were divided into an experimental group and a control group. Before starting this study, a pretest and a proficiency test were administered to both groups to find the homogeneity of the groups. The control groups received traditional instruction of grammar by another teacher. In traditional instruction the teacher first states the rules in the students' mother tongue then some exercises are provided for the students in order to practice the rules afterwards. Students were also required to do the exercises of the book related to each particular structure.

The experimental groups received task based instruction through all sessions; the researchers first introduced the tasks to the learners. The whole process lasted about 5 months and classes were held once a week. Conducting these tasks took 35 to 45 minutes per session. At the end, all of the groups received the post-test to assess the effects of task based grammar instruction in comparison to traditional ways of teaching grammar.

At the beginning and the end of the study, students filled out a questionnaire to measure of their motivation toward learning English. The effect of the TBLT on learners ' motivation was to be investigated. The 1st grade English book of high school was taught to both groups. They were at elementary level. At the beginning of the study, two pre-tests to ensure the English language knowledge as well as the grammar proficiency of the subjects were applied. After administering the pre-tests, the researchers started conducting the treatment and at the end of the experiment the posttests were administered in order to find answers to the research questions.

\section{Data Analysis}

\subsection{Performance of the Participants on the General Proficiency test}

The control and treatment group of learners' language proficiency were compared to ensure their comparability in providing answer for the questions of the study. All the participants were given the Nelson grammar proficiency test to make sure that they were all homogenous and elementary EFL learners. The estimated language proficiency mean of treatment group was 34.51 and that of control group was 34.00.

\subsection{Performance of the Learners on the Motivation Pre-test}

The participants of the treatment and control groups were decided as elementary EFL learner, and then the researchers compared the motivation of participants to ensure their comparability in providing answer for the second question of the study. As Tables 1 shows the mean and standard deviation for the control participants came to 2.8 and 1.2, respectively and the evaluated mean and standard deviation for the treatment participants came to 2.4 and 1.3, respectively. An independent-samples t-test that was run to measure the difference in the control and treatments' mean scores showed that there was no significant difference between them in terms of their motivation (Sig. $=0.94>0.05$ ).

Table 1. Results of motivation in both treatment and control group

\begin{tabular}{cccccc}
\hline & TBI & $\mathrm{N}$ & Mean & Std. Deviation & Std. Error Mean \\
\hline \multirow{2}{*}{ Pre-test } & TREATMENT & 39 & 2.4769 & 1.34326 & .21509 \\
\cline { 2 - 6 } & CONTROL & 35 & 2.8295 & 1.27632 & .21574 \\
\hline
\end{tabular}

\subsubsection{Performance of the treatment and control on the Post-test}

The first question of study states that 'Is Task-based instruction more effective than traditional grammar instruction on the learning of the grammatical structures by first grade high school students?'

The first null hypothesis of thesis states that 'There is no significant difference between traditional grammar instruction and Task-based instruction on first grade high school students.' 
To answer the first question of the study, the instructors ran a paired- sample t-test and independent sample test. The results of post-test were analysed to investigate any effect of TBI on the grammar proficiency of the learners more precisely. Tables 2 and 3 display the post-test results for the treatment and control groups. The estimated grammar proficiency development mean and standard deviation (Table 2) of the participants in the treatment group amounted to be 25.95 out of 30 , and 2.9 respectively, and the estimated grammar proficiency achievement mean score and standard deviation of the participants in the control group amounted to be 14.12 and 1.8 respectively. An inspection of the mean scores showed that there was a considerable difference between the treatment group and the control group in terms of overall grammar proficiency development. Moreover, the independent-samples t-test analysis showed that this difference was statistically significant $(\mathrm{p}=0.000)$. Therefore, the first null hypothesis is rejected (Table 3 ).

Table 2. Performance of the Participants on the Michigan Post-test

\begin{tabular}{llrrrrr}
\hline & TBI & N & Mean & Std. Deviation & Std. Error Mean \\
\hline TREATMENT & treatment group & 39 & 25.95 & 2.955 & .473 \\
\cline { 2 - 7 } & control group & 35 & 14.12 & 1.822 & .312 \\
\hline
\end{tabular}

Note. No. of Cases $=74$, mean for treatment and control $=25.9,14.1$

Table 2 displays the number of participants, mean value, standard deviation, and standard error of means, in both treatment and control groups.

Table 3. Independent Samples t-test Performance of the Participants on the Michigan Post-test

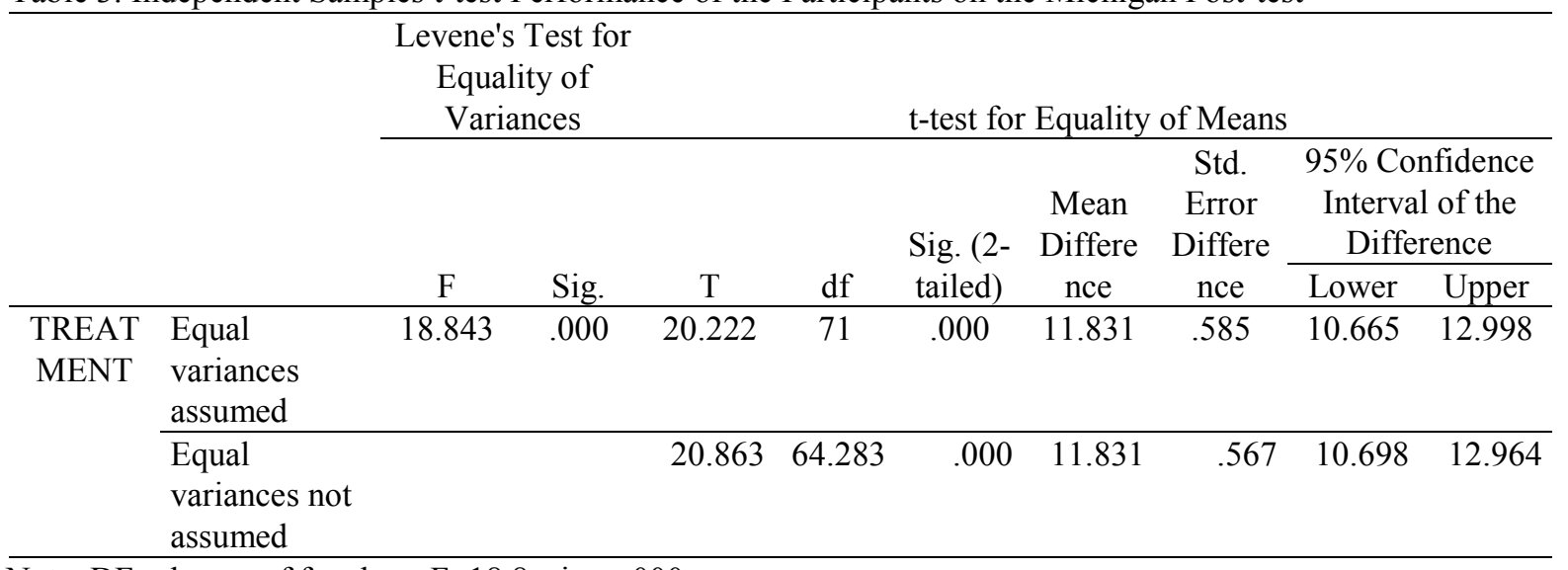

Note. $\mathrm{DF}=$ degree of freedom; $\mathrm{F}=18.8 ;$ sig. $=.000$

The independent-samples t-test for the performance of treatment and control groups on the pre-test is shown in table (3). Considering what is indicated in the table, we can find out the following results: Sig. $=p$-value $=0.000<0.05=$ a

\subsubsection{Performance of the Treatment Group on the Pre- and Post-test}

In order to find out to what extent the TBI has succeeded in promoting the grammar proficiency of the learners, the preand post-tests of each treatment and control groups were compared via paired-samples t-tests.

The comparison of the pre- and post-tests of the treatment group revealed a remarkable achievement in the grammar proficiency mean scores (Table 4) of the participants. The pre-test and post-test mean values of 7.79 and 26.03 as well as a significant level of $\mathrm{p}=0.045$ shows a great development in the grammar proficiency of the treatment participants (Table 4).

Table 4. Results of the Treatment Group on the Michigan Pre- and Post-test

\begin{tabular}{|c|c|c|c|c|c|}
\hline & & Mean & $\mathrm{N}$ & Std. Deviation & Std. Error Mean \\
\hline \multirow[t]{2}{*}{ Pair 1} & POSTTEST & 26.03 & 39 & 2.954 & .479 \\
\hline & PRETEST & 7.79 & 39 & 1.989 & .323 \\
\hline
\end{tabular}

Note. No. of Cases $=38$, mean for post and pre-test $=2.9,1.9$

Table 4 displays the number of participants, mean value, standard deviation, and standard error of means, in both treatment and control groups.

The figure 1 indicates the Results of the Treatment Group on the Michigan Pre- and Post-test more tangibly. 
Table 5. Results Paired Samples test of the Treatment Group on the Michigan Pre- and Post-test

\begin{tabular}{|c|c|c|c|c|c|c|c|c|}
\hline & \multicolumn{5}{|c|}{ Paired Differences } & \multirow[b]{3}{*}{$\mathrm{T}$} & \multirow[b]{3}{*}{ Df } & \multirow{3}{*}{$\begin{array}{l}\text { Sig. (2- } \\
\text { tailed) }\end{array}$} \\
\hline & \multirow[b]{2}{*}{ Mean } & \multirow{2}{*}{$\begin{array}{c}\text { Std. } \\
\text { Deviation }\end{array}$} & \multirow{2}{*}{$\begin{array}{l}\text { Std. Error } \\
\text { Mean }\end{array}$} & \multicolumn{2}{|c|}{$\begin{array}{l}95 \% \text { Confidence } \\
\text { Interval of the } \\
\text { Difference }\end{array}$} & & & \\
\hline & & & & Lower & Upper & & & \\
\hline $\begin{array}{ll}\text { Pair } & \text { POSTTEST - } \\
1 & \text { PRETEST }\end{array}$ & 18.237 & 2.972 & .482 & 17.260 & 19.214 & 37.823 & 37 & .000 \\
\hline
\end{tabular}

Note. $\mathrm{DF}=$ degree of freedom; $\mathrm{DF}=37$; sig. $=.000$

The paired samples statistics of the treatment group is shown in table (5). As indicated in this table, the mean scores of the subjects on the pre-test and post-test were 7 and 18.23 respectively.

The paired-samples t-test for the performance of treatment groups on the post-test is shown in table (5). Considering what is indicated in the table, we can find out the following results: Sig. $=$ p-value $=0.045<0.05=$ a

\subsubsection{Performance of the control Group on the Pre- and Post-test}

Although the comparison of the pre- and post-tests of the control group indicated achievement in grammar proficiency mean scores of the participants (Table 6), it was not a significant development. The pre-test and post-test mean values of 6.88 and 14.12 shows development in the participants' grammar ability but the level of $p=0.893$ obtained through paired samples t-test indicates no statistical difference in the grammar proficiency of the control participants.

Table 6. Results of the Control Group on the Michigan Pre- and Post-test

\begin{tabular}{llrrrr}
\hline & & Mean & N & Std. Deviation & Std. Error Mean \\
\hline \multirow{2}{*}{ Pair 1 } & POSTTEST & 14.12 & 35 & 1.822 & .312 \\
\cline { 2 - 6 } & PRETEST & 6.88 & 35 & 1.719 & .295 \\
\hline
\end{tabular}

Note. No. of Cases $=34$, mean for post and pre-test=2.9, 1.9

The paired samples statistics of this control group is shown in table (6). As indicated in this table, the mean scores of the subjects on the pre-test and post-test were 6.8 and 14.12 respectively.

Table 7. Results of Paired Samples t-test of the control Group on the Michigan Pre- and Post-test

\begin{tabular}{|c|c|c|c|c|c|c|c|c|c|}
\hline & \multicolumn{5}{|c|}{ Paired Differences } & \multirow[b]{3}{*}{$\mathrm{T}$} & \multirow[b]{3}{*}{$\mathrm{df}$} & \multirow{3}{*}{$\begin{array}{l}\text { Sig. (2- } \\
\text { tailed) }\end{array}$} \\
\hline & & \multirow[b]{2}{*}{ Mean } & \multirow{2}{*}{$\begin{array}{c}\text { Std. } \\
\text { Deviation }\end{array}$} & \multirow{2}{*}{$\begin{array}{l}\text { Std. Error } \\
\text { Mean }\end{array}$} & \multicolumn{2}{|c|}{$\begin{array}{l}95 \% \text { Confidence } \\
\text { Interval of the } \\
\text { Difference }\end{array}$} & & & \\
\hline & & & & & Lower & Upper & & & \\
\hline $\begin{array}{l}\text { Pair } \\
1\end{array}$ & $\begin{array}{l}\text { POSTTEST - } \\
\text { PRETEST }\end{array}$ & 7.235 & 2.475 & .424 & 6.372 & 8.099 & 17.047 & 33 & .000 \\
\hline
\end{tabular}

Note. $\mathrm{DF}=$ degree of freedom; $\mathrm{DF}=33 ;$ sig. $=.893$

The paired-samples t-test for the performance of control groups on the post-test is shown in table (7). Considering what is indicated in the table, we can find out the following results: Sig. $=$ p-value $=0.893>0.05=$ a .

In an attempt to accept or reject the first null hypothesis, the hypothesis that which stated that TBI had no significant effect on the grammar proficiency of Iranian elementary EFL learners, the researchers presented all the above obtained data via tables. The results rejected this hypothesis through the systematic analyses of the pre- and post-tests.

\subsection{Performance of the Participants on the motivation Post-test}

Research question two of the study examined the impact of TBI on motivation of the first grade high school students in improving their grammatical proficiency. To test the second null hypotheses of the study that predicted no significant effect of TBI on motivation of learners a sequence of pared sample - test and independent samples t-tests were conducted to compare the average scores of the experimental groups on the posttest.

The second research question of this study dealt with investigating the motivation level of learners after TBI instruction. It was hypothesized that task based instruction had no significant impact on the motivation of the learners in improving their grammatical proficiency. As mentioned in the analysis of research question one, task based method of teaching applied in the study was effective in promoting the grammatical proficiency of the learners. However, the following analyses were employed to answer the second research question. Paired sample and independent t-test were conducted to compare the mean scores of motivation groups. It revealed a significant difference in the mean scores of motivation. These findings indicated that TBI method used in this study had a significant effect on promoting the motivation of the Iranian elementary EFL learners. Therefore, the second null hypothesis is rejected at p-value less than 0.05 . 
Table 7 displays the number of participants, mean value, standard deviation, and standard error of means, in both treatment and control groups.

The figure (1) indicates the Results of the Performance of the Participants on the motivation Post-test more tangibly.

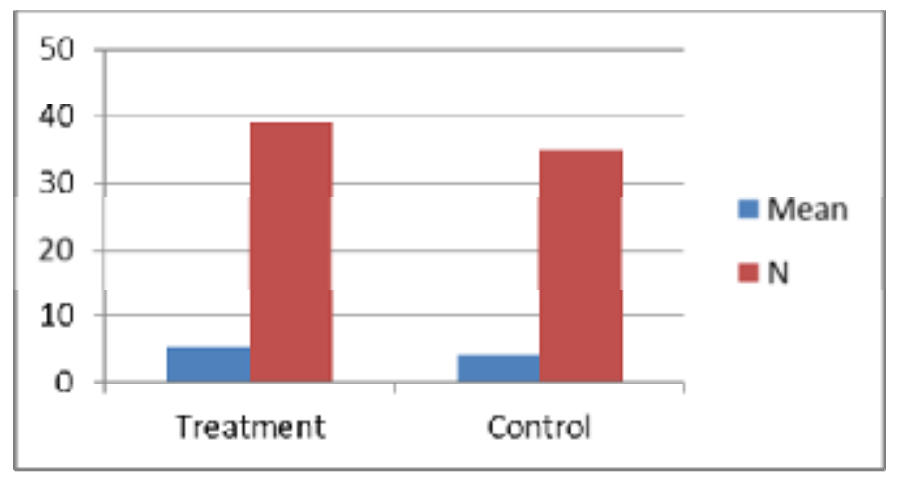

Figure 1. Results of the Performance of the Participants on the motivation Post-test

Table 8. Results Paired Samples test of the treatment Group on the Motivation Pre- and Post-test

\begin{tabular}{lllrrr}
\hline & Mean & N & Std. Deviation & Std. Error Mean \\
\hline Pair 1 & Pre-test & 2.4769 & 39 & 1.34326 & .21509 \\
\cline { 2 - 6 } & Post-test & 5.3496 & 39 & 1.16322 & .18627 \\
\hline
\end{tabular}

Note. $\mathrm{DF}=$ degree of freedom; $\mathrm{DF}=37$; sig. $=.000$

Table 8 displays the number of participants, mean value, standard deviation, and standard error of means, in both experimental and control groups.

Table 9. Results Paired Samples test of the treatment Group on the Motivation Pre- and Post-test

\begin{tabular}{llccc}
\hline & $\mathrm{N}$ & Correlation & Sig. \\
\hline Pair 1 & Pre-test \& post test & 39 & -.328 & .042 \\
\hline
\end{tabular}

The paired-samples t-test for the performance of treatment groups on the post-test is shown in table (9). Considering what is indicated in the table, we can find out the following results: Sig. $=$ p-value $=0.042<0.05=\mathrm{a}$

Table 10. Independent-samples t-test results for the motivation post-test of the treatment and control groups

\begin{tabular}{|c|c|c|c|c|c|c|c|c|c|c|}
\hline & & \multicolumn{2}{|c|}{$\begin{array}{c}\text { Levene's Test for } \\
\text { Equality of } \\
\text { Variances } \\
\end{array}$} & \multicolumn{7}{|c|}{ t-test for Equality of Means } \\
\hline & & \multirow[b]{2}{*}{$\mathrm{F}$} & \multirow[b]{2}{*}{ Sig. } & \multirow[b]{2}{*}{$\mathrm{t}$} & \multirow[b]{2}{*}{$\mathrm{df}$} & \multirow[b]{2}{*}{$\begin{array}{l}\text { Sig. (2- } \\
\text { tailed) }\end{array}$} & \multirow{2}{*}{$\begin{array}{c}\text { Mean } \\
\text { Differen } \\
\text { ce }\end{array}$} & \multirow{2}{*}{$\begin{array}{c}\text { Std. } \\
\text { Error } \\
\text { Differen } \\
\text { ce }\end{array}$} & \multicolumn{2}{|c|}{$\begin{array}{l}95 \% \text { Confidence Interval of } \\
\text { the Difference }\end{array}$} \\
\hline & & & & & & & & & Lower & Upper \\
\hline \multirow[t]{2}{*}{$\begin{array}{l}\text { Motivation } \\
\text { posttest }\end{array}$} & $\begin{array}{l}\text { Equal } \\
\text { variances } \\
\text { assumed } \\
\end{array}$ & 26.944 & .000 & 6.672 & 72 & .000 & 1.32481 & .19857 & .92896 & 1.72066 \\
\hline & $\begin{array}{l}\text { Equal } \\
\text { variances not } \\
\text { assumed }\end{array}$ & & & 7.032 & 39.749 & .000 & 1.32481 & .18840 & .94397 & 1.70566 \\
\hline
\end{tabular}

Note. $\mathrm{DF}=$ degree of freedom; $\mathrm{DF}=72 ; \mathrm{sig} .=.000$

The independent-samples t-test for the performance of treatment and control groups on the post-test is shown in table (10). Considering what is indicated in the table, we can find out the following results: Sig. $=$ p-value $=0.000>0.05=$ a .

\section{Discussions}

As was stated previously, this study examined whether applying TBI to Iranian elementary EFL learners had any effect on improving their grammar proficiency or not. Moreover, it also compared the effects of TBI on the motivation of control and treatment group. In what follows the findings of the study for the investigated research questions are discussed. 


\subsection{Research Question 1}

Returning to the research questions, one aim of this study was to answer the following question:

1- Is Task-based instruction significantly more effective than traditional grammar instruction on the grammar proficiency of the Iranian first grade high school students?

After examining the homogeneity of the experimental and control groups before treatment through administration of the Nelson language proficiency test, a standardized grammar test was administered as the pretests to both experimental and control groups to ensure the homogeneity of their knowledge of grammatical structures. After the treatment both groups were administered a posttest the same as pretest. To examine the impact of TBI on high school learners' grammatical proficiency, a couple of paired samples t-tests were used. The comparison of the pre- and post-tests displayed a considerable improvement in the grammatical proficiency mean scores of the participants. The participants of experimental group significantly improved their knowledge of the target structures from the mean score of 7.77 on the pretest to 26 on the posttest .P value was lower than 0.05 , so the null hypothesis for the first research question is rejected. Considering this research question, it is possible to claim that TBI do have significant effect on learners' grammatical knowledge and proficiency.

It is now possible to state that the mean score results of the grammar exam, which were administered after implementing TBI, indicated that the treatment group participants $(p<0.05)$ performed significantly better than those in the control group. Therefore, TBI has significantly affected the grammar proficiency of the elementary EFL learners.

The data generated in this study also suggest that implementing task based instruction at the elementary level of English language can help EFL learners improve their grammar performance. Although both the experimental and the control groups in received same length of time instruction, the experimental groups in revealed higher improvement and their mastery of the grammar structures was gained from performance of task activities. Therefore, one can argue that TBI causes such a progress.

\subsection{Research Question 2}

The second question that was examined in this study was:

Does task based instruction have any significant impact on the motivation of the learners in improving their grammatical proficiency?

After implementing TBI on elementary EFL learners, the researchers administered a motivation questionnaire to answer of the second question. Based on the results of this test, there is a significant impact on motivation of EFL learners after implementing TBI. The participants of experimental group significantly improved their motivation from the mean score of 2.4 on the pretest to 5.4 on the posttest .P value was lower than 0.05 , so the null hypothesis for the first research question is rejected. Considering this research question, it is possible to claim that TBI do have significant effect on learners' academic motivation.

These findings rejected the second null hypothesis that claimed task based instruction did not have any significant effect on the motivation of the students in improving their grammatical proficiency.

Many motivation theories believed that there is a positive relationship between educational motivation and educational performance, such as Gottfried (1990), Berndt \& Miller (1990), Pintrich \& De Groot (1990), Deci et la. (1991), Vallerand et la. (1992), Deci \& Ryan(2000), Marsh \& Hau (2004), Cokley \& Patel( 2007), and Areepattamannil \& Freeman (2008). The findings of this study also showed that the motivated students also performed better in the grammar test. This study also revealed that TBI has a significant impact on the motivation of the elementary EFL students.

Lochana and Deb's (2006) project in India,done by the Basaveshwara Education Society, also demonstrated evidence supporting TBI. Their results suggested that task-based instruction is helpful to learners not only in terms of proficiency development but also in terms of motivation. The present study is in line with Lochana and Deb's (2006) findings.

Richards and Rodgers (2001) mentioned that success in achieving the goals of task which is assumed by learners increases learners' motivation. Skehan (1998) argued "although task accomplishment always leads to a sense of satisfaction, the completed outcome of project-oriented tasks caused much more motivation and satisfaction". (p. 107). The present study is also in line with Richards and Rodgers (2001) and Skehan (1998).

Considering cognitive effect of tasks, findings of this study is in congruence with what Prabhu (1987) stated as one of the criteria for selecting task-based syllabuses. He believed that the tasks in language classes make a challenge and are motivate learners and provide them with a sense of achievement. The present study is in accordance with the findings of Prabhu (1987) in the fact that after implementing tasks, learners were more pleased and got more motivated to resume and perform more tasks.

\section{Conclusions and pedagogical implications of the study}

\subsection{Conclusion}

This study, although limited in scope, was an attempt to investigate the impact of TBI on promoting the grammatical proficiency of Iranian Elementary EFL learners, as well as to gauge the motivation of EFL leaners after implementing TBI. The survey indicated the significant influence of TBI on the grammatical proficiency of elementary EFL learners. The findings provided evidence that the learners who performed tasks became better motivated than those who didn`t 
which means that TBI had a positive and significant effect on the motivation of EFL learners who experienced grammar learning through this method of instruction.

\subsection{Pedagogical Implications of the Study}

Much information can be found by getting learners to do language tasks. Information of the study provides valuable data about the students' grammar learning and how to develop it. The results may be of relevance to task designers and teachers in better understanding the TBI. The type and amount of TBI in this study may give teachers a measure when deciding how much time to dedicate to structures. Studies such as these are likely to make teachers to feel comfortable applying TBL in language classes. Replication of the study to other populations is called for before accepting above conclusions with confidence.

\section{References}

Areepattamannil, S., \& Freeman, J. G. (2008). Academic achievement, academic self concept, and academic motivation of immigrant adolescents in the greater Toronto area secondary schools. Journal of Advanced Academics, 19, 700-743.

Batstone, R. (1994). Grammar. Oxford: Oxford University Press.

Berndt, T. J., \& Miller, K. E. (1990). Expectancies, values, and achievement in junior high school. Journal of Educational Psychology, 82, 319-326.

Branden, K. V. (2006). Task Based Language Education from theory to practice. cambridge: cambridge university press.

Brown, H. D. (2001). Teaching by principles:An integrative approach to language pedagogy. New York: Addison Wesley Longman.

Brown, H. D. (2007). Principels of language Learning and Teaching (5th edn). NY: Pearson education.

Bugler, D., \& Hunt, A. (2002). Implementing task-based language teaching. In J. C. Richards \& W. A. Renandya, Methodology in language teaching: Ananthology of current practice. Cambridge : Cambridge University Press.

Chang, S.-C. (2011). A Contrastive Study of Grammar Translation Method and Communicative Approach in Teaching English Grammar. English Language Teaching, 4(2), 13-24

Cokley, K., \& Patel, N. (2007). A psychometric investigation of the academic selfconcept of Asian American college students. Educational and Psychological Measurement, 67, 88-99.

Deci, E. L., \& Ryan, R. M. (2000). The "what" and "why" of goalpursuits: Human needs and the selfdetermination of behavior. Psychological Inquiry, 11, 227-268.

Eliss, R. (2003). Task-based language learning and teaching. Oxford: Oford University Press.

Fotos, S. and Ellis, R. (1991). Communicating about grammar: A task based approach. TESOL Quarterly, 25, 605-628.

Gottfried, A. E. (1990). Academic intrinsic motivation in young. Journal of Educational Psychology, 82,525 - 538.

Linse, C. T. (2005). Practical English language teaching: young learners. New York: a Second The McGraw-Hill

Littlejohn\& Hicks (1997) Cambridge English for Schools 3 work Book, Cambridge ,Cambridge University Press

Lochana, M. and Deb, G. (2006). Task based teaching: learning English without tears. Asian EFL Journal, 8(3), 140154.

Long, M.H. \& Norris, J.M. (2000). Task-based teaching and assessment. In M.Byram(ed.) encyclopedia of language teaching, p.597-603.. London:Routledge

Long, M. (1985). A role for instruction in second language acquisition: Task-based. In K. Hyltenstam, \& M. Pienemann, Modelling and assessing, 377-93.

Lopez, J. (n.d.). Introducing TBI for Teaching English in Brazil. Retrieved October 18, 2012 , http://etd.auu.et/dspace/\%E2\%80\%A6/1/Microsoft $\% 20-\% 20-\% 20$ tagesse

Marsh, H. W., \& Hau, K.T. (2004). Explaining paradoxical relations between academic selfconcepts and achievements: Crosscultural generalizability of the internal/external frame of reference predictions across 26 countries. Journal of Educational Psychology, 96(1):56-57.

Mohammadi. M. (2006). The effect of Task-based method on learning of There is/ There are in English. M.A Thesis. Isfahan, Isfahan University.(Persian).

Newby, D. (2003). Cognitive+Communicative Theory of Pedagogical Grammar. Habilitationsschrift: Karl-Francens Universität Graz.

Oxenden\& Latham-koeni (2008) American English File, Oxford, Oxford University Press

Pintrich, P. R, \& De Groot, E. V. (1990). Motivational and self-regulated Learing components of classroom academic performance. Journal of Educational Psychology, Vol.82, 33-40.

Prabhu, N. (1987). Second language pedagogy. Oxford: Oxford University Prees.

Richards , R. (2001). approaches and methods in language teaching. USA: Cambridge University Press. 
Robinson, P. (2013). The Routledge Encyclopedia of Second Language Acquisition. UK: Routledge .

Rogers, C. V., \& Medley, F. W. (1988).Language with a purpose: Using authentic materials in the foreign language classroom. Foreign Language Annals, 21, 467-478.

Ryan, R., \& Deci, E. L. (2000). Intrinsic and Extrinsic Motivations: Classic Definitions and New Directions. Contemporary Educational Psychology, 65, 54-57.

Schacter, D. (2011). PSYCHOLOGY. United States of America: Catherine Woods.

Skehan, P. (1998). A cognitive approach to language learning. Oxford: Oxford University Press.

Today, P. (2013). Motivation . Retrieved from psychology today: http://www.psychologytoday.com/

Ushioda, E. (2009). A person-in-context relational view of emergent motivation, self and identity. In Z. Dornyei \& E. Ushioda (Eds.), Motivation, language identity and the L2 self (pp. 215-228). Bristol: Multilingual Matters.

Vallerand, R. J., Pelletier, L. G., Blais, M. R., Brière, N. M., Senécal,. (1992). The academic motivation scale: A measure of intrinsic, extrinsic, and amotivation in education. Educational and Psychological Measurement, 52,10031017.

Willis, D., \& Willis, J. (2007)Doing task-based teaching. Oxford: Oxford University press.

Willis, J. (1996a). A framework for task-based learning. Harlow: Longman Addison.

Willis, J. (2007). Task-based language teaching:how teachers solve their problems. IATEFL Annual Conference Aberdeen. Fellow Aston University 